\title{
BIOETIČKI SENZIBILITET ZAKONA O ZAŠTITI OSOBA S DUŠEVNIM SMETNJAMA ${ }^{1}$
}

\author{
Prof. dr. sc. Velinka Grozdanić*
}

\author{
UDK: $342.7-056.37(497.5)(094.5 .072)$ \\ Ur.: 8. rujna 2017. \\ Pr.: 4. listopada 2017. \\ Izvorni znanstveni rad
}

\section{Sažetak}

Sve očigledniji raskorak između duhovnog razvoja čovjeka koji uglavnom stagnira, a nerijetko i nazaduje i tehnološkog razvoja društva koji intenzivno $i$ nezaustavljivo raste, otvara brojne bioetičke teme u širokom rasponu od brige za čovjeka i njegovo zdravlje do brige za prirodu i opstanak života u cjelini. Brojne etičke rasprave koje su obilježile posljednja desetljeća rezultirale su općeprihvaćenim etičkim načelima, ali isto tako su mnoga etička pitanja ostala bez jasnih $i$ nedvojbenih odgovora. U tom kontekstu pravna regulativa od koje se očekuje da zaštiti osobe od neprihvatljivih $i$ štetnih postupaka, ali $i$ da istovremeno ne bude prepreka znanstvenom i tehnološkom razvoju društva, dobiva posebno značenje. Riječ je o velikom izazovu jer kroz zakonske odredbe treba postići balans između slobode znanstvenog istraživanja i zaštite čovjeka. Iako etičke dvojbe prate gotovo svako područje ljudskoga djelovanja, bioetički sadržaji posebno su vezani uz neslućena tehnološka dostignuća u medicini. Pritom, jedna od najranjivijih skupina pacijenata, osobe s duševnim smetnjama zahtijeva naglašeni bioetički senzibilitet u smislu humanosti, razumijevanja $i$ pojačane osjetljivosti kod primjene etički upitnih medicinskih postupaka prema njima i osobito kod njihovog uključivanja u, ponekad i rizična, biomedicinska istraživanja. Temeljni zaštitni mehanizam za ovu kategoriju osoba u Republici Hrvatskoj je Zakon o zaštiti osoba s duševnim smetnjama. Njime je uspostavljen jasni pravni okvir za postupanje prema osobama s duševnim smetnjama te se neke njegove odredbe mogu smatrati konkretnim odgovorom na brojne etičke dileme. Analiza tih odredbi koja je predmetom ovoga rada može poslužiti kao relevantan pokazatelj bioetičkog senzibiliteta Zakona o zaštiti osoba s duševnim smetnjama.

\footnotetext{
* Dr. sc. Velinka Grozdanić, redovita profesorica Pravnog fakulteta Sveučilišta u Rijeci; velinka@ pravri.hr

1 Ovaj rad je sufinancirala Hrvatska zaklada za znanost projektom IP-11-2013-2287 „Legal Status and Real Position of People with Mental Difficulties - Interdisciplinary Approach and European Perspectives" i Sveučilište u Rijeci potporama znanstvenim istraživanjima 13.08.1.3.02 "Interdisciplinarni pristup u istraživanju statusa osoba s duševnim smetnjama kroz prizmu konvencijskog prava".
} 
Ključne riječi: Zakon o zaštiti osoba s duševnim smetnjama, informirani pristanak, bioetika, biomedicinska istraživanja.

„Briga za čovjeka i njegovu sudbinu mora uvijek biti glavni cilj svih tehnoloških nastojanja sa svrhom da učinci našega rada budu blagoslov, a ne prokletstvo za ljudski rod." Albert Einstein

\section{1. $U V O D$}

Riječ „bioetika“ u razdoblju od svega nekoliko desetljeća osvojila je prostor ljudskoga razmišljanja i djelovanja i nametnula se kao nezaobilazna partnerica u raspravama o brojnim etičkim dilemama današnjega svijeta. ${ }^{2} \mathrm{Za}$ ovaj „osvajački pohod" bioetike postojali su jasni razlozi i jaki argumenti. Intenzivan razvoj prirodnih znanosti i novih tehnologija posljednjih desetljeća otvorio je ili ponovno aktualizirao pitanje granica ljudskoga djelovanja, odnosno granice zahvata čovjeka u njegov unutarnji i vanjski svijet.

Cjelokupna povijest čovječanstva konstantno svjedoči i uvijek iznova potvrđuje, da čovjek puno lakše mijenja svijet oko sebe nego samoga sebe. Taj očigledni i sve veći nesklad između znanstveno-tehnološkog i duhovnoga razvoja čovjeka nosi u sebi prijetnju samouništenja onoga što danas nazivamo civilizacijom suvremenog društva. I upravo bioetika koja je nastala kao spontani pokret, a s vremenom izrasla u respektabilnu znanstvenu disciplinu, nastoji otvaranjem etičkih pitanja koja prate znanstvena istraživanja u svim područjima ljudskoga djelovanja, ukazati na brojne etičke dvojbe, potaknuti rasprave o njima i time doprinijeti osvješćivanju problematike koja se dotiče svakoga živog bića, a samo ju čovjek koji ju je i prouzročio može i riješiti.

Tijekom svoga korištenja riječ bioetika mijenjala je i širila svoje značenje. ${ }^{3}$

2 Tvorac riječi bioetika bio je onkolog Van Rensselaer Potter, koji je 1971. godine spojio dvije grčke riječi: bios - život i ethike - etika i prema kojem je bioetika znanost ravnoteže između čovjeka i prirode i most prema budućnosti čovječanstva. Iste je godine opstetričar Andre Hellegers stavio riječ bioetika u naziv svoga instituta kojeg je osnovao u Washingtonu pod nazivom Kenedy institut za izučavanje ljudske reprodukcije i bioetiku, svodeći taj pojam na medicinsku etiku. Više o tome, v. Reich, W.: How Bioethics Got Its Name, Hastings Center Report, Special Supplement, 23., 1993., 6-7. U novije vrijeme pojavila se informacija da je njemački teolog i pastor Fritz Jahr još 1927. godine u popularno znanstvenom časopisu Kosmos prvi upotrijebio naziv Bio-Ethik. V. Čović, A.: Pojmovna razgraničenja: moral, etika, medicinska etika, bioetika, integrativna bioetika, Hrestomatija hrvatskog Medicinskog prava (ur. K. Turković, S. Roksandić Vidlička i A. Maršavelski), Pravni fakultet, Zagreb, 2016., str. 6.

3 Više o različitim definicijama boetike, v. Šegota, I.: Kako definirati bioetiku, Bioetika u teoriji i praksi, Nakladni zavod Globus, Zagreb, 2001., str. 77.- 93. 
Tako je od bioetike shvaćene kao profesionalne etike u medicini, preko „poslovne etike“, „pravne etike“, „ekološke etike“, ,,agrikulturne etike“, „,socijalne etike“, itd. prerasla u ,globalnu bioetiku“. Danas bi se moglo reći da taj pojam sve više poprima svoje izvorno značenje „znanost o opstanku“, odnosno svoje doslovno značenje „etika života" kao etičko promišljanje o životu i moralno djelovanje u svim njegovim segmentima.

Iako etička dimenzija prati gotovo svaki oblik čovjekova djelovanja, bioetički sadržaji u velikoj mjeri okupirani su brojnim dvojbama koje nameću nezaustavljiva i neslućena znanstvena i tehnološka dostignuća u medicini. Molekularno-genetička dijagnostika, kloniranje stanica, transplantacija organa sa životinja na ljude, gensko liječenje, manipulacije rasplodnim materijalom, eutanazija, biomedicinska istraživanja, samo su neka pitanja koja još uvijek traže primjerene odgovore.

Iza svih etičkih dilema u medicini, sadašnjih i budućih, koje će donijeti daljnji ubrzani razvoje medicinske tehnologije stoji temeljno pitanje odnosa liječnika prema pacijentu. To je neobično složen odnos između onoga tko treba pomoć i onoga koji je pruža, između nemoći i moći, između neznanja i znanja, između inferiornosti i superiornosti, između nekompetencije i kompetencije. Međutim, ponajprije to je odnos čovjeka prema čovjeku. I to je nedvojbena činjenica koju nikada, niti u jednom slučaju, niti u jednom trenutku, ne treba zanemariti. Ta činjenica možda opterećuje, ograničava, uznemirava, obvezuje, ali isto tako ona jača odgovornost liječnika, izgrađuje povjerenje pacijenata, pa i cjelokupnoga društva prema razvoju medicine, humanizira medicinsku djelatnost i pruža solidno uporište za ispravne odgovore na brojne etičke dileme u ovom području. I možda nas upravo ta spoznaja, da odnos „liječnik i pacijent“ treba uvijek biti odnos „,̌ovjeka prema čovjeku“, više nego sva druga individualna i društvena nastojanja približava starom, dobro poznatom i jednostavnom zlatnom pravilu ,ne čini drugima što ne želiš da drugi čine tebi“. Iako je riječ o potpuno jasnom, gotovo samorazumljivom načelu, ono je za čovjeka još uvijek nedostižno. Stoga se prostor djelovanja u medicini koji se kreće u širokom rasponu od dobrog, ispravnog, odgovornog, korektnog, moralnog do lošeg, neispravnog, neodgovornog, nekorektnog, nemoralnog mora urediti ne samo etičkim, već i pravnim normama. Jasno da se rečeno odnosi i na sva druga područja ljudskoga djelovanja, međutim bolestan čovjek čije zdravlje, a nerijetko i život, ovise o odlukama liječnika pripada najranjivijoj društvenoj skupini, što potencira nužnost jasnih moralnih standarda, ali i zahtijeva obvezujuću pravnu regulativu u postupanju prema njima.

\section{PRAVNA REGULATIVA ETIČKIH DILEMA U MEDICINI}

Suvremena društva svoju stabilnost ostvaruju društvenim normama tako da utvrđujući primjereno i prihvatljivo ponašanje svih članova reguliraju odnose među ljudima, a time i red u samoj zajednici. Najčešće je riječ o općeprihvaćenim pisanim ili nepisanim društvenim pravilima koja se oslanjaju na moralne norme, čije uvažavanje i poštovanje u svakodnevnom životu počiva na uvjerenju većine o njihovoj nužnosti za postizanje socijalne ravnoteže i prihvatljivoga društvenog poretka. Među mnogobrojnim normama posebno mjesto pripada pravnim pravilima 
kojima se društveni odnosi prisilno uređuju, bilo da se određena ponašanja zabranjuju (prohibitivne norme) ili da se nalažu (imperativne norme). Drugim riječima, samo iza pravnih normi stoji država s represivnim aparatom, sa sustavima sankcija za prekršitelje pravnih pravila. Tako pravne norme, putem zabrana ili naloga s jedne strane i kazni s druge, utječu na ponašanja ljudi usmjeravajući ih prema jedinstvenom prisilnom redu koji odgovara interesima, ciljevima i vrijednosnom sustavu u nekoj društvenoj zajednici. Stoga se može reći da su pravne norme sasvim jasna poruka o vrijednostima koje se u nekom društvu zaštićuju i promiču.

Iako demokratskoj slici društva odgovara da se konfliktne životne situacije rješavaju sa što manje prisile, današnja društva pravnim pravilima sve više zadiru u brojne društvene odnose. Ta težnja da se brojni odnosi uređuju pravnim pravilima osobito dolazi do izražaja u zajednicama u kojima etičke vrijednosti gube svoju snagu. Štoviše, može se reći da što su etičke norme u funkciji regulatora čovjekova ponašanja slabije, to je potreba za prisilnim pravnim normama snažnija.

Izniman i moglo bi se reći nemjerljiv doprinos u pravnoj zaštiti čovjeka odigrao je koncept ljudskih prava. Zahtjevi za zaštitom ljudskih prava kroz povijest prošli su vrlo dugačak, ali i uspješan put od ideje o prirodnim pravima i temeljnim slobodama čovjeka do uspostavljanja normativnog i institucionalnog okvira za njihovu zaštitu. ${ }^{4}$ Tako danas postoje brojni pravni dokumenti univerzalnog, regionalnog ili nacionalnog dometa koji zaštićujući temeljna ljudska prava i slobode čovjeka nastoje odgovoriti izazovima i opasnostima modernih tehnologija.

Brojna etička pitanja vezana uz medicinu kroz konvencijsko pravo dobila su svoj pravni okvir, a tek neka od njih i jasan zakonski odgovor. Naime, nužno je naglasiti da pravo kao konzervativan i prilično inertan sustav nije u stanju pratiti brzi tehnološki napredak medicinske znanosti. Pored toga, za brojne etičke dvojbe koje su izravan rezultat toga napretka još uvijek ne postoje niti približno usuglašeni stavovi. Upravo suprotno, mnoga etička pitanja dobivaju sasvim različite odgovore ovisno o tomu daju li odgovore liječnici, teolozi, antropolozi, filozofi, pravnici, sociolozi ili neke druge zainteresirane društvene skupine. Stoga će pravo u demokratskim društvima vrlo oprezno, poštujući pluralitet mišljenja, svojom zakonodavnom intervencijom zahvaćati samo u one etičke konflikte za koje može ponuditi, barem za većinu prihvatljiva etička rješenja. I pritom će posebno voditi računa da ne postane zapreka znanstvenim, tehničkim i tehnološkim inovacijama u području biologije i medicine, ali i da postavi jasnu granicu u zaštiti bolesnih osoba od neprihvatljivih, nedopuštenih i štetnih medicinskih postupaka. Riječ je o velikom izazovu jer treba postići ravnotežu između slobode znanstvenog istraživanja i zaštite čovjeka. U tom kontekstu u području

4 Danas postoji golemi corpus juris na području zaštite ljudskih prava među kojima posebno mjesto pripada Povelji Ujedinjenih naroda iz 1945., Općoj deklaraciji o ljudskim pravima iz 1949., Međunarodnom paktu o građanskim i političkim pravima i Međunarodnom paktu o gospodarskim, socijalnim i kulturnim pravima iz 1966. U europskom sustavu zaštite ljudskih prava posebno su važne Europska konvencija za zaštitu ljudskih prava i temeljnih sloboda iz 1950., Europska socijalna povelja iz 1960. te Europska konvencija o sprječavanju mučenja, nečovječnog ili ponižavajućeg postupanja ili kažnjavanja iz 1957., više o tome, v. Grozdanić, V.: Kaznena djela protiv slobode i prava čovjeka i građanina, u Posebni dio kaznenog prava, (ur. Novoselec, P.), Zagreb, 2007., str. 51.-53. 
medicinske prakse iskristalizirali su se stavovi oko nekih etičkih dilema pa su tako, npr. pitanja poštovanja ljudskoga dostojanstva svakog čovjeka, a osobito bolesnog i nemoćnog, informirani pristanak za primjenu liječničkog tretmana ili sudjelovanja u biomedicinskim istraživanjima kao izraz autonomije i samoodređenja, kao i zaštita tajnosti medicinskih informacija u funkciji zaštite privatnosti, ali i uspostavljanja povjerenja između liječnika i pacijenta, dobila detaljnu pravnu regulativu u brojnim zakonima uključujući i kaznenopravnu zaštitu putem kaznenoga zakonodavstva. Ova transformacija etičkih rasprava, najprije u općeprihvaćena etička načela, a potom u njihovo preoblikovanje u pravna pravila promijenila je i retoriku, pa se umjesto o dobrom ili lošem ponašanju raspravlja o zakonitom ili nezakonitom djelovanju.

I ovi nedvojbeni zakonski odgovori, međutim, dobivaju novu dimenziju kada se radi o posebno ranjivoj skupini pacijenata, o osobama s duševnim smetnjama. Naime, ponekad njihova mentalna kompetentnost zbog duševnih smetnji može biti narušena u mjeri koja čini upitnom njihovu mogućnost donošenja ispravnih odluka o prihvaćanju ili ne prihvaćanju određenih medicinskih postupaka. Pored toga, ako se uzme u obzir i uvijek prisutna stigmatizacija koja prati osobe s duševnim smetnjama, zbog koje se nepravedno, a moglo bi se reći i nerazumno, gotovo iracionalno svrstavaju u jednu od najneprihvatljivih društvenih skupina, potreba istančanog senzibiliteta prema njima nameće se sama po sebi. Ovaj naglašeni bioetički senzibilitet kao izraz humanosti, razumijevanja i osobite naklonosti prema osobama s duševnim smetnjama zahtijeva posebnu zakonsku regulativu, poseban pravni mehanizam koji će ih štititi od nepotrebnih prisilnih intervencija, od etički upitnih medicinskih postupaka (psihokirurgija, kastracija, elektrokonvulzivno liječenje) i sudjelovanja u za njih nekorisnim, a možda i štetnim i opasnim biomedicinskim istraživanjima, kad već oni sami to ne mogu. Taj lex specialis, taj poseban zaštitni mehanizam u Republici Hrvatskoj je Zakon o zaštiti osoba s duševnim smetnjama.

Zakon o zaštiti osoba s duševnim smetnjama (u daljnjem tekstu: ZZODS) nastoji svojim odredbama uspostaviti jasan pravni okvir, ali i nametnuti obvezujuća načela, postupke i konkretne uvjete u postupanju prema osobama s duševnim smetnjama, radi osnaživanja njihove pravne pozicije, a time i stvarnoga položaja u situacijama u kojima im je neophodna liječnička pomoć. ${ }^{5}$ Izradu zakona pratila su mnogobrojna etička iskušenja pa se stoga i mnoga zakonska rješenja mogu smatrati konkretnim odgovorom na brojne etičke dvojbe u ovom području. Pritom treba jasno naglasiti da su zakonska rješenja svoje uporište imala u Ustavu Republike Hrvatske i konvencijskom pravu Svjetske zdravstvene organizacije, Vijeća Europe, Vijeća Europske unije i Opće skupštine Ujedinjenih naroda kojima su uspostavljeni visoki standardi zaštite osoba $\mathrm{s}$ duševnim smetnjama te u bogatoj praksi Europskog suda za ljudska prava, koji je svojim odlukama potvrđivao te standarde. ${ }^{6}$

Propitivanje sadržaja Zakona o zaštiti osoba s duševnim smetnjama, analiza i ocjena odredbi o informiranom pristanku osoba s duševnim smetnjama ili njihovih

5 Zakon o zaštiti osoba s duševnim smetnjama, Narodne novine, br. 76/2014., na snazi je od 1. siječnja 2015. godine. Inače, prvi takav zakon pod istim nazivom u Republici Hrvatskoj donesen je 1997. godine (Narodne novine br. 111/1997., 27/1998., 128/1999., 79/2002.).

6 Više o tome u: Komentar Zakona o zaštiti osoba s duševnim smetnjama, (ur. Grozdanić, V.), Rijeka, 2015., str. XIV.-XVII i str. 319.- 430. 
surogata (osobe od povjerenja ili zakonskog zastupnika) na primjenu posebnih medicinskih postupaka i sudjelovanja u biomedicinskim istraživanjima mogu biti dobri pokazatelji bioetičkoga senzibiliteta samoga zakona.

\section{INFORMIRANI PRISTANAK OSOBA S DUŠEVNIM SMETNJAMA}

Koncept informiranog pristanka ${ }^{7}$ stožerno je etičko načelo u liječničkoj praksi koje je svoj obvezujući pravni izričaj dobilo u konvencijskom pravu i u nacionalnom zakonodavstvu. Informirani pristanak potvrđuje autonomiju pacijenta, njegovo pravo na samoodređenje i pravo da slobodno bira medicinske postupke koje sam ocjenjuje najboljim za sebe. Autonomija pacijenta u velikoj je mjeri suzila paternalistički pristup po kojemu je liječnik kao stručnjak donosio odluke za dobrobit pacijenta. Moglo bi se reći da je upravo načelo autonomije, pacijenta iz objekta postavilo u položaj subjekta koji surađujući s liječnikom odgovorno donosi odluke o svom zdravlju. A da bi donio ispravnu odluku mora ga se na jednostavan, jasan i za njegovu dob, obrazovanje i mentalne sposobnosti razumljiv način informirati o njegovoj bolesti, mogućnostima izlječenja, eventualnim rizicima pri odabiru pojedinih metoda liječenja ili odbijanja predloženih metoda liječenja itd. Pritom se podrazumijeva sposobnost pacijenta da razumije informacije koje dobiva od liječnika i da posjeduje dostatne intelektualne kapacitete za donošenje odluka, odnosno za davanje ili uskraćivanje pristanka za određene medicinske postupke. I dok za većinu pacijenata te sposobnosti nisu upitne, kod psihijatrijskih pacijenata duševne smetnje mogu u kraćem ili dužem trajanju umanjiti mentalne sposobnosti u mjeri da osoba nije u stanju razumjeti informacije, pa tako niti dati valjani pristanak za poduzimanje određenog dijagnostičkog ili terapijskog postupka. Stoga je informiranom pristanku osoba s duševnim smetnjama kroz odredbe ZZODS-a posvećena posebna pozornost.

Tako je već u općim odredbama ZZODS definirao pristanak kao slobodno danu suglasnost osobe s duševnim smetnjama za primjenu određenoga medicinskog postupka koja se temelji na odgovarajućem poznavanju svrhe, prirode, posljedica, koristi i rizika toga medicinskog postupka i drugih mogućnosti liječenja (čl. 3. st. 1. t. 13.). Povrh toga, zakonodavac je jasno propisao da se osobu s duševnim smetnjama može podvrgnuti medicinskom postupku samo uz njezin pisani pristanak koji može opozvati u bilo kojem trenutku (čl. 12. st. 1.). Budući da se za primjenu svakoga medicinskog postupka zahtijeva pisani pristanak, da bi isključio mogućnost različitih interpretacija, u ZZODS-u je definiran i pojam „medicinski postupak“ kao prijem, zadržavanje i smještaj u psihijatrijsku ustanovu te dijagnostički postupak i liječenje osobe s duševnim smetnjama (čl. 3. st.1. t. 4.). Razumije se da pisani pristanak mora biti rezultat slobodno izražene volje psihijatrijskog pacijenta da prihvati predloženi

7 O informiranom pristanku postoji brojna literatura. V., npr. Faden, R. R., Beauchamp, T., King, N. M.: A History and Theory of Informed Consent, Oxford University Press, New York, 1986.; Frković, A.: Bioetika u kliničkoj praksi, Pergamena, Zagreb, 2006., str. 63.-100.; Beauchamp, T. L. i Childress, J., F.: Principles of Biomedical Ethics, Oxford University Press, Oxford, 2013., str. 101.-141. 
medicinski postupak te da je svaki oblik pritiska, nagovaranja, obmanjivanja nepotpunim ili netočnim informacijama suprotan smislu instituta informiranog pristanka.

Budući da kod psihijatrijskih pacijenata sposobnost za davanje pristanka može biti sporna, u ZZODS-u je predviđeno da se prije davanja pristanka mora utvrditi sposobnost osobe s duševnim smetnjama za davanje pristanka (čl. 12. st. 2). Pored toga, u svrhu sprječavanja proizvoljnosti, manipulacija ili olakoga proglašavanja nesposobnim za donošenje odluke onih osoba s duševnim smetnjama koje uskraćuju pisani pristanak za primjenu određenoga medicinskog postupka, ZZODS je propisao kriterije po kojima se procjenjuje sposobnost za davanje pristanka. Tako se osobu s duševnim smetnjama koja može razumjeti informaciju koja je važna za davanje pristanka, upamtiti tu informaciju i koristiti ju u postupku davanja pristanka, ne može proglasiti nesposobnom za davanje pristanka. Sve navedeno odnosi se i na osobe s duševnim smetnjama koje su lišene poslovne sposobnosti. Drugim riječima, a prema izričitoj zakonskoj odredbi, lišenje poslovne sposobnosti ne znači nesposobnost za davanje pristanka pa se, prije primjene medicinskoga postupka, sposobnost za davanje pristanka mora utvrđivati i kod osobe lišene poslovne sposobnosti (čl. 12 . st. 3.). Time se uvažava životna činjenica da ista osoba može biti nesposobna za, npr. financijske transakcije, ali potpuno sposobna za donošenje odluka o svom zdravlju. Iznimku od navedenoga predstavljaju hitni slučajevi ozbiljne i izravne ugroženosti života i zdravlja osobe s duševnim smetnjama u kojima se medicinski postupci mogu primijeniti i bez utvrđivanja sposobnosti za davanje pristanka i bez traženja pristanka, ali samo dok traje ta ugroženost (čl. 12. st. 4.).

Koncept informiranoga pristanka odrazio se i na brojna druga prava psihijatrijskih pacijenata kojima im je osigurana aktivna uloga u postupku vlastitog izlječenja. Tako pored prava biti upoznata s razlozima i ciljevima svog smještaja u psihijatrijsku ustanovu te sa svrhom, prirodom, posljedicama, koristima i rizicima provedbe predloženoga medicinskog postupka, osoba $\mathrm{s}$ duševnim smetnjama ima pravo biti upoznata s podacima o svom zdravstvenom stanju i dobiti na uvid svoju medicinsku dokumentaciju. Isto tako psihijatrijski pacijenti u psihijatrijskim ustanovama imaju pravo sudjelovati u planiranju i provođenju svojeg liječenja, rehabilitaciji i resocijalizaciji (čl. 14. st. 1. t. 2., 4. i 5.).

Navedena, ali i brojna druga prava osoba s duševnim smetnjama, sadržana u ZZODS-u korespondiraju s obvezama odjelnih liječnika ili voditelja odjela psihijatrijske ustanove u kojoj je osoba smještena. Pa tako, da bi psihijatrijski pacijenti mogli ostvarivati sva svoja prava, ali i biti aktivni sudionici u procesu svog izlječenja, psihijatri su dužni podučiti ih o njihovim pravima i načinu kako ih mogu ostvariti, a isto tako redovito ih informirati o njihovu zdravstvenom stanju i medicinskim postupcima koji se primjenjuju prema njima. Kvalitetno informiranje, uz uvažavanje potreba, mišljenja i želja osoba s duševnim smetnjama, otvara prostor za dobru komunikaciju i suradnički odnos između psihijatara i njihovih pacijenata. Ujedno se stvara i povjerenje da se predloženi medicinski postupci primjenjuju u njihovom najboljem interesu, čime se postiže dobrovoljno prihvaćanje medicinskih postupaka. Odnos suradnje između psihijatra i osobe s duševnim smetnjama je conditio sine 
qua non za ostvarenje brojnih temeljnih načela ZZODS-a: načela autonomije, načela najboljeg interesa osobe s duševnim smetnjama, načela dobrovoljnosti prihvaćanja medicinskih postupaka, načela primjene minimalnih ograničenja i, svakako, vodećega načela koje prožima cijeli zakonski sadržaj, a to je načelo zaštite dostojanstva osoba s duševnim smetnjama.

Nema nikakve sumnje da je za realizaciju bilo kojega dobrog suradničkog odnosa između liječnika i pacijenta potrebno mnogo razumijevanja i strpljenja. Međutim, ponekad ni uz puno dobre volje psihijatra nikakav suradnički odnos neće biti moguće uspostaviti ako se radi o osobi s težim duševnim smetnjama ${ }^{8}$ koja zbog psihičkog poremećaja nije u mogućnosti izraziti svoju volju. Za takve situacije ZZODS je u odredbama o „Smještaju bez pristanka“ predvidio zamjenski pristanak zakonskoga zastupnika. Drugim riječima, osoba s težim duševnim smetnjama koja nije sposobna dati pristanak može se liječiti u psihijatrijskoj ustanovi temeljem pisanog pristanka roditelja ili skrbnika. Zamjenski pristanak zakonskoga zastupnika uobičajeno je rješenje u situacijama u kojima osoba ne može sama izraziti svoje pristajanje ili nepristajanje na pojedine medicinske postupke. Ovo rješenje temelji se na pretpostavci da će pacijentu bliska osoba, umjesto samog pacijenta, donositi za njega najbolje i najispravnije odluke. Međutim, brojni su slučajevi iz prakse Europskog suda za ljudska prava osporili ovu pretpostavku pokazujući da su neki zakonski zastupnici donosili odluke u svoju korist, a ne u korist osoba koje su zastupale. ${ }^{9}$ Stoga je ZZODS uveo dodatne zaštitne mehanizme obvezujući psihijatrijske ustanove da o svakom smještaju bez pristanka bez odgode obavijeste Pravobranitelja za osobe s invaliditetom koji ima ovlaštenje da, ako posumnja u opravdanost smještaja temeljem zamjenskoga pristanka zakonskog zastupnika, o tomu obavijesti nadležni sud i tako inicira postupak sudske zaštite osobe s težim duševnim smetnjama. Sudsku zaštitu psihijatrijska ustanova je dužna odmah i izravno inicirati i ako se osoba koja je u psihijatrijsku ustanovu smještena bez pristanka usprotivi pristanku svog zakonskog zastupnika.

Navedenom regulativom zakonodavac je nastojao osigurati sudsku zaštitu psihijatrijskim pacijentima koji su smješteni u psihijatrijske ustanove bez svoga pristanka, a na temelju zamjenskoga pristanka zakonskog zastupnika. Ipak, kako bi pro futuro u što većoj mjeri za punoljetne osobe s duševnim smetnjama isključio zamjenski pristanak ponekad spornoga zakonskog zastupnika te osigurao poštovanje volje samoga pacijenta, ZZODS je uveo i detaljno regulirao institut obvezujuće izjave. Riječ je, o tzv. anticipiranim naredbama u slučaju buduće nesposobnosti očitovanja volje. Naime, ovim institutom svaka osoba može izjavom ovjerenom kod javnog bilježnika ovlastiti osobu od povjerenja da umjesto nje daje ili uskraćuje pristanak na

8 ZZODS težu duševnu smetnju definira kao poremećaj prema važećim međunarodno priznatim klasifikacijama mentalnih poremećaja, koja po svojoj naravi ili intenzitetu ograničava ili otežava psihičke funkcije osobe u mjeri u kojoj joj je neophodna psihijatrijska pomoć (čl. 3.st .1.t. 17). Više o međunarodnim klasifikacijama mentalnih poremećaja, v. Goreta, M.: Errare humanum est - najčešće pogreške u forenzičko-psihijatrijskoj praksi, Naklada Slap, Jastrebarsko, 2015., str. 21.-24.

9 Tako npr. ESLJP, Shtukaturov protiv Rusije, zahtjev br. 44009/05 od 27. ožujka 2008.; ESLJP, Sykora protiv Češke, zahtjev br. 23419/07 od 13. studenog 2008. 
određene medicinske postupke. Time se osigurava poštovanje njezinih želja o izboru i prihvaćanju dijagnostike, liječenja i smještaja u psihijatrijsku ustanovu u trenutku kada ona svoje želje zbog duševnog poremećaja neće moći valjano iskazati. Drugim riječima, osoba unaprijed u vrijeme kada je sposobna o tomu odlučivati određuje pravila o svom liječenju koja obvezuju osobu od povjerenja, a preko nje i sve one koji sudjeluju u njezinom liječenju, kada ona to više ne bude u stanju činiti. U osobi od povjerenja, koju je sama osoba s duševnim smetnjama ovlastila da umjesto nje daje ili odbije dati pristanak na određeni medicinski postupak, jača se autonomija i samoodređenje psihijatrijskih pacijenata i čuva njihovo dostojanstvo jer se prema njima postupa na način koji su oni sami odabrali. No, postoje i situacije u kojima zamjenski pristanak zakonskoga zastupnika ili osobe od povjerenja nema nikakvu ulogu. Riječ je o pristanku za primjenu elektrokonvulzivnog liječenja i pristanku na sudjelovanje u biomedicinskim istraživanjima.

\subsection{Informirani pristanak za primjenu elektrokonvulzivnog liječenja}

Elektrokonvulzivno liječenje zajedno s psihokirurgijom i kastracijom pripada skupini posebnih medicinskih postupaka. Od njihovog uvođenja u psihijatrijsku praksu prate ih brojne dvojbe među kojima etičke imaju vrlo veliku ulogu. Naime, njihova je primjena $u$ povijesti bila često zloupotrebljavana, a i danas zbog svoje invazivne prirode mogu biti rizične za osobe nad kojima se primjenjuju. Stoga pravna regulativa posebnih medicinskih postupaka ide uglavnom u pravcu zabrane njihove primjene. Tako su primjena psihokirurgije prema osobi s duševnim smetnjama i kastracija $\mathrm{u}$ svrhu njihove sterilizacije prema regulativi ZZODS-a izričito zabranjene. Međutim, elektrokonvulzivno liječenje se i dalje može primjenjivati prema osobama s duševnim smetnjama, ali uz ispunjenje precizno postavljenih zakonskih uvjeta, čime se u znatnoj mjeri ograničava polje njihove primjene. Prvi uvjet za primjenu elektrokonvulzivne terapije pisani je pristanak osobe s duševnim smetnjama. Ovaj pristanak podrazumijeva da je osoba dobro informirana o ovoj terapijskoj metodi i svim njezinim pozitivnim i negativnim učincima te da je nedvojbeno utvrđeno da je osoba sposobna za davanje takvog pristanka. Ako osoba nije sposobna za davanje pristanka, zamjenski pristanak ne može dati ni zakonski zastupnik niti osoba od povjerenja. Pored pisanoga pristanka osobe na koju se treba primijeniti elektrokonvulzivno liječenje zakonodavac zahtijeva da su prethodno iscrpljeni svi ostali postupci liječenja, zatim da postoji mišljenje odjelnog liječnika o opravdanosti očekivanja stvarne i izravne koristi od primjene ove metode te izostanak štetnih popratnih posljedica i da postoji pozitivno mišljenje etičkog povjerenstva psihijatrijske ustanove o etičkoj prihvatljivosti njegove primjene. Prema tomu može se reći da, iako je elektrokonvulzivno liječenje zadržano kao još uvijek opravdani terapijski pristup u pojedinim slučajevima, ova četiri kumulativno postavljena uvjeta znatno sužavaju, pa čak i isključuju primjenu ove kontraverzne psihijatrijske metode. ${ }^{10}$

10 O vrlo različitim stajalištima vezano uz konvulzivnu terapiju, v. npr. Shorter, E. i Healy, D.: Shock Therapy, A History of Electroconvulsive Treatment in Mental Illness, Rutgers University Press, New Brunswick, 2007., u kojoj se autori zalažu za primjenu ove metode prema 
Isključivanjem mogućnosti zamjenskog pristanka za primjenu elektrokonvulzivnog liječenja, primjena ovoga medicinskog postupka potpuno je isključena kod djece odnosno kod osoba koje nisu navršile osamnaest godina života jer njih do njihove punoljetnosti i stjecanja poslovne sposobnosti zastupaju njihovi zakonski zastupnici. To je u skladu s prevladavajućim stručnim stavom da je pri eventualnom indiciranju elektrokonvulzivnog liječenja iznimno važno imati na umu kako takvo liječenje nije primjereno te zahtijeva ,,preliminarnu eliminaciju“ same te metode kod pacijenata sa specifičnim rizičnim dispozicijama kao što su dječja ili adolescentna dob u ranom razvoju. ${ }^{11}$

Pored djece, od primjene ove metode isključene su i sve punoljetne osobe koje nisu sposobne dati svoj pristanak. No, kako se elektrokonvulzivno liječenje primjenjuje kod životno rizičnih psihijatrijskih pacijenata (teška endogena depresija, shizofreni stupor), moglo bi se postaviti pitanje opravdanosti isključenja ove metode iz razloga što pacijent nije u mogućnosti izjasniti se prihvaća li ju ili odbija. Ovo pitanje otvara, prije svega, etičku dvojbu o primjeni metode za koju sama psihijatrijska struka nema jedinstvenoga stava i to o njezinoj učinkovitosti i o posljedicama koje može proizvesti. Stoga se može reći da je svojim restriktivnim stavom prema primjeni elektrokonvulzivnog liječenja zakonodavac poslao jasnu poruku da se ovaj sporni medicinski postupak koji može i pomoći, ali i odmoći osobi s duševnim smetnjama u procesu njezina liječenja, ne smije primjenjivati bez suglasnosti samog pacijenta. Tako je jedna etička dvojba dobila svoj pravni izričaj koji je u potpunosti usklađen s temeljnim načelima (načelom dostojanstva, autonomije, dobrovoljnosti i informiranog pristanka) i zaštitnom svrhom ZZODS-a.

\subsection{Informirani pristanak za sudjelovanje u biomedicinskim istră̌ivanjima}

U području bioetike interes za medicinska istraživanja posebno je izražen. Naime, istraživanja u medicini neophodna su za razvoj medicinske znanosti od koje se očekuju rješenja za brojne zdravstvene probleme. Istodobno njihova provedba može dovesti do povrede ljudskih prava i ljudskoga dostojanstva o čemu u povijesti medicinskih eksperimenata nad ljudima ima obilje primjera. Dovoljno je podsjetiti na nečovječne medicinske eksperimente u „logorima smrti“ tijekom Drugog svjetskog rata, ali i na Nirnberško suđenje nacističkim liječnicima za zločine počinjene obavljanjem medicinskih eksperimenata u koncentracijskim logorima. ${ }^{12}$ Ovo suđenje iznjedrilo je čuveni Nirnberški kodeks koji je, nastojeći zadovoljiti moralni, etički

određenim kategorijama psihijatrijskih bolesnika ili npr. Read, J.: Electroconvulsive Therapy, objavljeno u: Read, J., Mosher, L:, Bentall, R. (ur.): Models of Madness: Psychological, Social and Biological Approaches to Schizophrenia, Brunner-Routledge, Hove, New York, 2004., str. 95.-96., koji nudi argumentiranu kritiku protiv elektrokonvulzivnog liječenja.

11 Više o neprimjerenosti elektrokonvulzivnog liječenja kod pojedinih kategorija pacijenata v. u Komentar Zakona o zaštiti osoba s duševnim smetnjama, op.cit. u bilj. 5. str. 83.

12 V. Vidlička, S. R. i Galiot, V.: Eksperimenti nad ljudima kao zločin protiv čovječnosti: od Nirnberškog medicinskog suđenja do predmeta Pfizer, Godišnjak Akademije pravnih znanosti Hrvatske, br. 1/2016., vol. VII, str. 186.-245. 
i pravni koncept u eksperimentiranju nad ljudima, donio temeljna načela koja se pritom moraju poštovati. Prvo njegovo načelo glasi: Dobrovoljni pristanak ispitanika apsolutno je ključan. To znači da osoba koja sudjeluje u eksperimentu mora imati poslovnu sposobnost za davanje pristanka, mora biti u stanju donijeti slobodan izbor, bez upliva bilo kakvog elementa prisile, prijevare, obmane, prinude, opsjene ili bilo kojeg drugog oblika prinude ili prisile, i mora posjedovati odgovarajuće znanje $i$ razumjeti ono o čemu se provodi istraživanje kako bi shvatila i donijela ispravnu (prosvijetljenu, svjesnu) odluku. ${ }^{13}$ Stoga se može reći da je Kodeks postavio temelje etičkim načelima u provođenju biomedicinskih istraživanja nad ljudima, odnosno da je uspostavio jasan etički kriterij koje osobe uopće mogu biti uključene u istraživanja.

Brojni drugi međunarodni dokumenti iz kasnijih godina slijedili su prvo i temeljno načelo Nirnberškog Kodeksa. ${ }^{14}$ Tako je, npr. Međunarodnim paktom o građanskim i političkim pravima (1966.) propisano da nitko ne smije biti podvrgnut mučenju ili okrutnom, nečovječnom ili ponižavajućem postupanju ili kažnjavanju. Osobito je zabranjeno podvrgnuti osobu medicinskom ili znanstvenom pokusu bez njezina slobodnog pristanka (čl. 7.). ${ }^{15}$

U tom kontekstu iznenađuje da je najvažnija konvencija koja je donesena nekoliko desetljeća kasnije, a nastala je radi zaštite temeljnih sloboda i prava čovjeka, Konvencija o ljudskim pravima i biomedicini (1997.), odstupila od zahtjeva za informiranim i slobodnim pristankom uključivanju u znanstvena istraživanja. ${ }^{16}$ Naime, ova konvencija uz zamjenski pristanak (odobrenje zakonskoga zastupnika ili organa vlasti ili osobe ili nekoga drugog tijela koje predviđa zakon) omogućava uključivanje u istraživanje i osobe koja nije sposobna dati pristanak za istraživanje (čl. 17. st. 1.). Pritom su u istom članku propisani i dodatni uvjeti koji moraju biti ispunjeni, pa se tako zahtijeva da rezultati istraživanja mogu proizvesti stvarnu i izravnu korist za zdravlje osobe na kojoj se provodi istraživanje te da se istraživanja usporedive učinkovitosti ne mogu provoditi na pojedincima koji su sposobni dati pristanak. Posljednji uvjet da dotična osoba nema prigovora čini se u najmanju ruku neuvjerljiv jer se radi o osobama koje nisu sposobne za davanje pristanka pa ostaje nejasno kakav bi to prigovor upućen s njihove strane mogao biti relevantan. Međutim, ono što u regulativi ove konvencije posebno zabrinjava jest iznimka predviđena $u$ stavku 2. istoga članka, po kojem se istraživanje bez pristanka prema osobama koje nisu sposobne dati pristanak može provesti i kada samo istraživanje nema mogućnosti proizvesti rezultate izravno korisne za zdravlje te osobe, a pod uvjetom da je cilj

13 Nirnberški kodeks dijelom je presude koju je Američki vojni tribunal donio u predmetu Sjedinjene Američke Države protiv Karla Brandta, 19. kolovoza 1947., a objavljen je u Dickenson, D., Huxtable, R., Parker, M.: The Cambridge Medical Ethics Workbook, Cambridge University Press, Cambridge, New York, Melbourn, 2010. ,str. 96.-97.

14 Za pregled relevantne međunarodne regulative vezane uz medicinska istraživanja nad ljudima, v. Fluss, S. S.: Contributions of International Organizations, u: Bioethics: From Ethics to Law, from Law to Ethics, Zürich, 1997., str. 194.-197.

15 Međunarodni pakt o građanskim i političkim pravima, Narodne novine - Međunarodni ugovori, br. $12 / 1993$.

16 Puni naziv Konvencije glasi „Konvencija o zaštiti ljudskih prava i dostojanstva ljudskog bića u pogledu primjene biologije i medicine: Konvencija o ljudskim pravima i biomedicini“ (1997.), Narodne novine - Međunarodni ugovori 13/2003., 18/2003. 
istraživanje pridonijeti znatno boljem znanstvenom razumijevanju stanja bolesti ili poremećaja pojedinca te pridonijeti konačnom postizanju rezultata koji mogu koristiti dotičnoj osobi ili drugim osobama koje su pogođene istom bolešću, ili poremećajem, ili se nalaze $\mathrm{u}$ istom stanju. Ova iznimka dovela je u pitanje temeljno pravilo iz Konvencije pod nazivom ,Zaštita osoba koje nisu sposobne dati pristanak“, u kojem je propisano da se zahvati prema osobi koja nije sposobna dati pristanak mogu izvršiti samo na njezinu izravnu korist (čl .6. st .1.). Ono što treba posebno naglasiti je činjenica da je tom iznimkom, po kojoj je moguće uključiti osobu koja ne može dati pristanak u istraživanje i onda kada nema mogućnosti da rezultati istraživanja budu od izravne koristi za tu osobu, dovedeno u pitanje i temeljno načelo Konvencije koje u članku 2. pod nazivom „Primat ljudskog bića“ propisuje da interesi i dobrobit ljudskoga bića imaju prednost pred samim interesom društva ili znanosti. Ova očigledna proturječnost unutar sadržaja Konvencije dovodi u pitanje njezinu proklamiranu svrhu, pa i sam njezin smisao.

Godine 2006. donesena je Konvencija o pravima osoba s invaliditetom radi promicanja, zaštite i osiguravanja punog i ravnopravnog uživanja ljudskih prava i temeljnih sloboda svih osoba $\mathrm{s}$ invaliditetom i promicanje poštovanja njihovog urođenog dostojanstva. ${ }^{17}$ Polazeći od urođenog dostojanstva, osobne autonomije, uključujući slobodu osobnog izbora i neovisnost osoba, ova Konvencija posebno naglašava da nitko neće biti podvrgnut medicinskim ili znanstvenim pokusima bez svojeg slobodnog pristanka (čl. 15. st. 1.). I pri ovom stavu ostaje dosljedna ne predviđajući nikakve izuzetke. Drugim riječima, osobe s duševnim smetnjama koje ne mogu dati pristanak ne mogu ni sudjelovati u medicinskim istraživanjima.

Zakon o zaštiti osoba $\mathrm{s}$ duševnim smetnjama u odredbama o primjeni biomedicinskih istraživanja prema osobama s duševnim smetnjama imao je uporište u Nirnberškom kodeksu, Konvenciji o pravima osoba s invaliditetom i Ustavu Republike Hrvatske, koji također propisuje da nitko ne smije biti podvrgnut bilo kakvom obliku zlostavljanja ili, bez svoje privole, liječničkim ili znanstvenim pokusima (čl. 23.).

Osjetljiva materija uključivanja osoba s duševnim smetnjama u biomedicinska istraživanja zahtijeva vrlo preciznu zakonsku regulativu, pa je ZZODS propisao pet kumulativnih uvjeta koje je potrebno ispuniti da bi se nad osobom s duševnim smetnjama provelo biomedicinsko istraživanje. Prvi je uvjet da projekt biomedicinskog istraživanja odobri Povjerenstvo za zaštitu osoba s duševnim smetnjama ${ }^{18}$ i to nakon preispitivanja znanstvenoga značaja, važnosti cilja i etičnosti istraživanja. Zatim je potrebno pribaviti pozitivno mišljenje etičkog povjerenstva ${ }^{19}$ o etičkoj prihvatljivosti

17 Osobe s invaliditetom definirane su kao osobe koje imaju dugotrajna tjelesna, mentalna, intelektualna ili osjetilna oštećenja, koja u međudjelovanju s različitim preprekama mogu sprečavati njihovo puno i učinkovito sudjelovanje u društvu na ravnopravnoj osnovi s drugima (čl. 1. st. 2.), Konvencija o pravima osoba s invaliditetom i Fakultativni protokol uz Konvenciju o pravima osoba s invaliditetom, Narodne novine - Međunarodni ugovori, 6/2007., 3/2008., $5 / 2008$.

18 Osnivanje Povjerenstva za zaštitu osoba s duševnim smetnjama smatra se dodatnim mehanizmom u zaštiti ove posebno ranjive kategorija osoba. Njegove nadležnosti, sastav i način rada propisani su u čl. 74., 75. i 76. ZZODS-a.

19 Riječ je o etičkom povjerenstvu psihijatrijske ustanove, odnosno o etičkom povjerenstvu 
uključivanja osobe $\mathrm{s}$ duševnim smetnjama u istraživanje. Nadalje, traži se pisani pristanak psihijatrijskoga pacijenta temeljen na poznavanju važnosti istraživanja, njegovoj svrsi, prirodi, posljedicama, koristima i rizicima koji se može opozvati u svakom trenutku, a kojemu je prethodilo utvrđivanje sposobnosti za davanje pristanka na biomedicinska istraživanja i to psihijatra izvan zaposlenika psihijatrijske ustanove koja provodi istraživanje, a kojeg je odredilo Povjerenstvo za zaštitu osoba s duševnim smetnjama. Posljednji je uvjet mišljenje odjelnog liječnika da se opravdano očekuje da će rezultati istraživanja biti korisni za zdravlje te osobe i bez štetnih popratnih posljedica (čl. 19., st. 1.). I kada se pribave sva navedena pismena, čelnik psihijatrijske ustanove donosi odluku o uključivanju osobe s duševnim smetnjama u biomedicinsko istraživanje (čl. 19., st. 2.). Kako ne bi postojale bilo kakve dvojbe zakonodavac je i kod biomedicinskih istraživanja izričito isključio mogućnost zamjenskoga pristanka te time još jednom potvrdio svoj stav o uvažavanju osobne autonomije, prava na izbor, neovisnost, a time i dostojanstva osoba s duševnim smetnjama.

U kontekstu navedenih zakonskih uvjeta za primjenu elektrokonvulzivnog liječenja i biomedicinskih istraživanja treba skrenuti pozornost na važnost redovitog vođenja potpune i precizne medicinske dokumentacije o zdravstvenom stanju osobe s duševnim smetnjama. Naime, zakonodavac je izričito propisao da se svaki medicinski postupak mora unijeti u medicinsku dokumentaciju s naznakom je li bio poduzet $\mathrm{s}$ pisanim pristankom ili bez njega (čl. 23., st. 1.). ${ }^{20}$ Pored toga, u posebnom je članku odredio da se bilješka o primjeni posebnih medicinskih postupaka (elektrokonvulzivno liječenje), bilješka o primjeni biomedicinskih istraživanja kao i sva druga pismena (pisani pristanak, mišljenja, odobrenja) moraju unijeti u medicinsku dokumentaciju (čl. 20., st. 1.). Zato je upravo medicinska dokumentacija relevantna u eventualnim sudskim postupcima zbog povrede prava psihijatrijskih pacijenata, jer se na temelju podataka koji se u njoj nalaze mogu pravilno utvrđivati činjenice važne za donošenje sudske odluke. ${ }^{21}$

Na kraju nužno je istaknuti da je ZZODS predvidio prekršajne odredbe i novčano kažnjavanje za nepoštovanje odredbi koje su u izravnoj funkciji zaštite osoba $\mathrm{s}$ duševnim smetnjama. Tako zaštita osoba s duševnim smetnjama nije prepuštena dobroj volji, savjesti ili etičkim prosudbama onih koji su obvezni po njima postupati. Propisivanjem, a potom i sankcioniranjem postupaka koji su suprotni zakonskoj regulativi, ZZODS je dao jasan i nedvojben odgovor etičkim dilemama u liječenju

zdravstvene ustanove u čijem se sastavu nalazi psihijatrijska jedinica.

20 Medicinski postupci bez pristanka psihijatrijskih pacijenata vezani su uz prisilno zadržavanje i prisilni smještaj osoba s težim duševnim smetnjama, koje zbog tih smetnji ozbiljno i izravno ugrožavaju vlastiti ili tuđi život, zdravlje ili sigurnost i neubrojivih osoba za koje je u kaznenom postupku utvrđeno da su u stanju neubrojivosti počinile protupravno djelo. Prisilni smještaj u psihijatrijsku ustanovu moguć je jedino odlukom suda, a ZZODS je u svojim odredbama detaljnom i preciznom regulativom tih postupaka nastojao osigurati maksimalnu pravnu zaštitu tim osobama.

21 Tako je u predmetu Bureš protiv Češke, zahtjev br. 37679/08 od 18. listopada 2012., Europski sud za ljudska prava utvrdio povredu prava podnositelja za zaštitu od nečovječnog i ponižavajućeg postupanja u vrijeme kada su u psihijatrijskoj ustanovi nad njime primjenjene mjere prisile, između ostalog jer zdravstvena ustanova nije vodila odgovarajuću medicinsku dokumentaciju u vezi s primjenom tih mjera. 
psihijatrijskih pacijenata $\mathrm{i}$ to osobito kod primjene spornih posebnih medicinskih postupaka i provođenja biomedicinskih istraživanja.

\section{ZAKLJUČAK}

Nema nikakve dvojbe da u cjelokupnom ljudskom stvaralaštvu etika ima iznimno važnu ulogu. Brojne etičke dileme suvremenoga društva kao rezultat njegovoga tehničkog i tehnološkog napretka potaknule su interdisciplinarnu i multidisciplinarnu raspravu koja se s vremenom oblikovala u znanstvenu disciplinu poznatu pod nazivom bioetika. U području medicine koja se i smatra izvorištem bioetike, tehnološki napredak zahtijeva etičke interpretacije, a ponekad i jasnu pravnu regulativu.

Uloga prava nije zaustavljati napredak medicinske znanosti već zaštitom temeljnih ljudskih prava i sloboda pacijenata držati medicinu u njoj imanentnim okvirima humanosti, korisnosti, dobrobiti i etičnosti. Štoviše, upravo pravna regulativa daje etički legitimitet medicinskim dvojbenim tretmanima i istraživanjima, ali samo pod uvjetom da se nacionalnim i međunarodnim pravnim pravilima propisani uvjeti beziznimno i poštuju. Drugim riječima, utvrđujući svojim pravilima uvjete za primjenu etički spornih medicinskih radnji, pravo, ne samo da štiti čovjeka od neprimjerenog zadiranja medicine u njegov tjelesni i psihički integritet, već štiti i dignitet medicinske znanosti.

Središnje mjesto ne samo u etičkim načelima već i u pravnoj normativi zauzima načelo dostojanstva čovjeka. Ono u području liječenja podrazumijeva autonomiju pacijenta, njegovu neovisnost, samoodređenje, pravo izbora, ali i odgovornost za svoje odluke. U tom kontekstu slobodan, informirani pristanak pacijenta na medicinske postupke i istraživanja postaje ključni čimbenik u odnosu između liječnika i pacijenta. I to je nešto što danas više nije ili ne bi trebalo biti sporno.

Dvojbenim se mogu pokazati samo neke konkretne situacije u kojima pacijenti nisu u stanju zbog teških psihičkih poremećaja izraziti svoju volju pa tako niti ostvariti svoje pravo na informirani pristanak za primjenu nad njima određenih medicinskih postupaka. I upravo je takvim pacijentima koji nisu u stanju sami donositi odluke o svom zdravlju potrebna posebna pravna zaštita.

Najvažniji pravni mehanizam u zaštiti psihijatrijskih pacijenata u Republici Hrvatskoj je Zakon o zaštiti osoba s duševnim smetnjama. Štoviše, u odnosu na sve ostale propise koji svojom regulativom zahvaćaju i pravni položaj osoba s duševnim smetnjama ovaj zakon je lex specialis, pa će se u slučaju različitog reguliranja istog sadržaja uvijek primjenjivati ZZODS. Prateći pojedina njegova rješenja kojima se regulira informirani pristanak, zamjenski pristanak zakonskoga zastupnika i osobe od povjerenja, primjena etički spornih metoda liječenja te uključivanje osoba s duševnim smetnjama u biomedicinska istraživanja, može se zaključiti da je ovaj zakon pokazao jak bioetički senzibilitet. Ne treba naravno imati iluzije da će bilo koji, pa ni ovaj zakon, riješiti sve etičke probleme u liječenju psihijatrijskih pacijenata $u$ psihijatrijskim ustanovama. Međutim, za nadati se da se jasna poruka o dostojanstvu osoba s duševnim smetnjama koju promiče cjelokupni sadržaj i duh ovog Zakona više neće moći ignorirati. 


\section{LITERATURA}

1. Beauchamp, T. L. i Childress, J. F.: Principles of Biomedical Ethics, Oxford University Press, Oxford, 2013.

2. Čović, A.: Pojmovna razgraničenja: moral, etika, medicinska etika, bioetika, integrativna bioetika, objavljeno u: Turković, K., Roksandić Vidlička, S. i Maršavelski, A. (ur. ): Hrestomatija hrvatskog medicinskog prava, Pravni fakultet, Zagreb, 2016., str. 3.-9.

3. Dickenson, D., Huxtable, R., Parker, M.: The Cambridge Medical Ethics Workbook, Cambridge University Press, Cambridge, New York, Melbourn, 2010.

4. ESLJP, Burě̌ protiv Češke, zahtjev br. 37679/08 od 18. listopada 2012.

5. ESLJP, Shtukaturov protiv Rusije, zahtjev br. 44009/05 od 27. ožujka 2008.

6. ESLJP, Sykora protiv Češke, zahtjev br. 23419/07 od 13. studenog 2008.

7. Faden, R. R., Beauchamp, T., King, N. M.: A History and Theory of Informed Consent, Oxford University Press, New York, 1986.

8. Fluss, S. S.: Contributions of International Organizations, objavljeno u: Bioethics: From Ethics to Law, from Law to Ethics, International colloquium, Lausanne, 17.-18. October, 1996., Publications of the Swiss Institute of Comparative Law, Zürich, 1997., str. 189.-204.

9. Frković, A.: Bioetika u kliničkoj praksi, Pergamena, Zagreb, 2006.

10. Goreta, M.: Errare humanum est - najčešće pogreške u forenzičko-psihijatrijskoj praksi, Naklada Slap, Jastrebarsko, 2015.

11. Grozdanić, V.: Kaznena djela protiv slobode i prava čovjeka i građanina, objavljeno u Novoselec, P. (ur.): Posebni dio kaznenog prava, Pravni fakultet Sveučilišta, Zagreb, Zagreb, 2007., str. 51.-74.

12. Grozdanić, V. (ur.): Komentar Zakona o zaštiti osoba s duševnim smetnjama, Pravni fakultet Sveučilišta u Rijeci, Rijeka, 2015.

13. Konvencija o pravima osoba s invaliditetom i Fakultativni protokol uz Konvenciju o pravima osoba s invaliditetom, Narodne novine - Međunarodni ugovori br. 6/2007., 3/2008., 5/2008.

14. Konvencija o zaštiti ljudskih prava i dostojanstva ljudskog bića u pogledu primjene biologije i medicine: Konvencija o ljudskim pravima i biomedicini (1997.), Narodne novine - Međunarodni ugovori br. 13/2003., 18/2003.

15. Međunarodni pakt o građanskim i političkim pravima, Narodne novine - Međunarodni ugovori br. 12/1993.

16. Read, J.: Electroconvulsive Therapy, objavljeno u: Read, J., Mosher, L:, Bentall, R. (ur.): Models of Madness: Psychological, Social and Biological Approaches to Schizophrenia, Brunner-Routledge, Hove, New York, 2004., str. 85.-100.

17. Reich, W.: How Bioethics Got Its Name, The Hastings Center Report, Special Supplement, vol. 23, br. 6, 1993., str. 6.-7.

18. Shorter, E. i Healy, D.: Shock Therapy, A History of Electroconvulsive Treatment in Mental Illness, Rutgers University Press, New Brunswick, New Jersey, London, 2007.

19. Šegota, I.: Kako definirati bioetiku, objavljeno u: Kurjak, A. i Silobrčić, V. (ur.): Bioetika u teoriji i praksi, Nakladni zavod Globus, Zagreb, 2001., str. 77.- 95.

20. Vidlička, S. R. i Galiot, V.: Eksperimenti nad ljudima kao zločin protiv čovječnosti: od Nirnberškog medicinskog suđenja do predmeta Pfizer, Godišnjak Akademije pravnih znanosti Hrvatske, vol. 7, br. 1, 2016., str. 186.-253.

21. Zakon o zaštiti osoba s duševnim smetnjama, Narodne novine, br. 76/2014. 


\section{Velinka Grozdanić*}

Summary

\section{BIOETHICAL SENSIBILITY OF THE LAW ON PROTECTION OF PERSONS WITH MENTAL DIFFICULTIES}

A more and more obvious gap between the human spiritual development, which mostly stagnates, and often even regresses, and the technological development of society, which intensively and unstoppably grows, has been the initiation of numerous bioethical discussions that cover a wide range of topics, i.e. from a concern for a man and his health to a concern for nature and preservation of life in general. No matter the fact that numerous ethical discussions, which highlighted the last decade, have resulted with commonly accepted principles, several ethical issues were left without clear and unambiguous solutions. Within this context, the legal regulations expected to protect persons from unacceptable and harmful actions, but at the same time not to present an obstacle to scientific and technological development of society, have gained a special meaning. This is a significant challenge due to the fact that through statutory provisions we need to reach a balance between the freedom of scientific research and protection of a man. Although ethical dilemmas follow almost every field of human actions, bioethical contents are especially associated with the unimaginable technological achievements in medicine. Thereby, persons with mental difficulties, as one of the most vulnerable groups of patients, demand a highlighted bioethical sensibility within the meaning of humanity, understanding and enhanced awareness when ethically questionable medical procedures are applied on them, and especially when these patients are included in, sometimes even hazardous, biomedical researches. A basic protective mechanism for this category of persons in the Republic of Croatia is the Law on Protection of Persons with Mental Difficulties. The Law establishes a clear legal framework to proceed with actions designated for persons with mental difficulties, and certain legal provisions embodied within the Law could be considered a quite concrete answer to numerous ethical dilemmas. The analysis of these provisions discussed in this paper may be used as a relevant indicator of bioethical sensibility of the Law on Protection of Persons with Mental Difficulties.

Keywords: Law on Protection of Persons with Mental Difficulties, informed consent, bioethics, biomedical research.

* Velinka Grozdanić, Ph. D., Full Professor, Faculty of Law, University of Rijeka; velinka@ pravri.hr. 
Zussamenfassung

\section{BIOETHISCHE SENSIBILITÄT DES GESETZES ÜBER DEN SCHUTZ VON PERSONEN MIT SEELISCHEN STÖRUNGEN}

Immer offensichtlichere Diskrepanz zwischen der am meisten stagnierenden und oft zurückgehenden geistigen Entwicklung des Menschen und der intensiv und unaufhaltsam wachsenden technologischen Gesellschaftsentwicklung eröffnet viele bioethische Themen von der Sorge um die Menschen und ihre Gesundheit bis zu der Sorge um die Natur und das Fortbestehen des Lebens. Obwohl es in den letzten Jahrzehnten zahlreiche ethische Diskussionen gab, woraus sich allgemein anerkannte ethische Grundsätze ergaben, wurden viele ethische Fragen unklar beantwortet. Von besonderer Bedeutung in diesem Kontext ist die Gesetzesregulative, von welcher erwartet wird, dass sie vor unakzeptablen und schädlichen Verhalten schützt, aber auch gleichzeitig kein Hindernis für die wissenschaftliche und technologische Gesellschaftsentwicklung darstellt. Es geht um eine große Herausforderung, weil man im Gesetz ein Gleichgewicht zwischen der Freiheit wissenschaftlicher Forschung und des Menschenschutzes erzielen muss. Obwohl ethische Dilemmas mit jedem Bereich menschlichen Handelns eng verbunden sind, können bioethische Themen und ungeahnte technologische Entwicklungen in der Medizin nicht voneinander getrennt werden. Dabei erfordert der Umgang mit Personen mit seelischen Störungen als einer der verletzbarsten Patientengruppe erhöhte bioethische Sensibilität im Sinne der Menschlichkeit, des Verständnisses und der Sensibilität bei der Anwendung ethisch fraglicher medizinischer Vorgehen, insbesondere bei den manchmal riskanten biomedizinischen Forschungen. Das Gesetz über den Schutz von Personen mit seelischen Störungen stellt den grundlegenden Schutzmechanismus in der Republik Kroatien für diese Personenkategorie dar. Mit diesem Gesetz wurde ein einheitlicher Rechtsrahmen für das Vorgehen gegenüber den Personen mit seelischen Störungen bestimmt, so dass manche Gesetzesbestimmungen als Antworten auf zahlreiche ethische Dilemmas angesehen werden können. Die Analyse dieser Bestimmungen in der vorliegenden Arbeit kann als ein relevantes Anzeichen für die bioethische Sensibilität des Gesetzes über den Schutz von Personen mit seelischen Störungen dienen.

\section{Schlüsselwörter: Gesetz über den Schutz von Personen mit seelischen Störungen, informierte Einwilligung, Bioethik, biomedizinische Forschungen.}




\author{
Riassunto
}

\title{
LA SENSIBILITÀ BIOETICA DELLA LEGGE SULLA PROTEZIONE DELLE PERSONE CON DISTURBI MENTALI
}

Il divario tra lo sviluppo spirituale dell'uomo, che normalmente è in fase di stallo, ma che non raramente pure regredisce, e lo sviluppo tecnologico della società, il quale cresce in maniera esponenziale, apre numerose questioni bioetiche, partendo dalla cura dell'uomo e della sua salute fino alla cura per la natura e la sopravvivenza della vita nell'intero. Numerosi dibattiti etici che hanno caratterizzato gli ultimi decenni sono sfociati in principi etici largamente condivisi; ma al contempo, molte altre questioni etiche sono rimaste senza chiare ed incontrovertibili risposte. In tale contesto, la normativa giuridica dalla quale ci si aspetta che tuteli le persone da procedimenti inaccettabili e dannosi, così come che al contempo non sia di ostacolo allo sviluppo scientifico e tecnologico della società, si riempie di un significato particolare. Si tratta di una grande sfida, poiché attraverso le disposizioni di legge occorre raggiungere l'equilibrio tra la libertà della ricerca scientifica e la tutela dell'uomo. Sebbene i dubbi etici accompagnino quasi ogni campo dell'agire umano, i contenuti bioetici sono collegati in particolare modo con inaspettati traguardi tecnologici in campo medico. Di qui l'esigenza avvertita da uno dei gruppi di pazienti maggiormente vulnerabili, e cioè le persone affette da disturbi mentali, di acuire la sensibilità bioetica nel senso della sua umanità, comprensione e del rafforzamento della premurosità nella pratica di procedure mediche di dubbia eticità nei loro confronti ed in particolare in occasione della loro inclusione in ricerche biomediche, che alle volte sono anche rischiose. Il meccanismo di fondo posto a tutela di detta categoria di persone nella Repubblica di Croazia è la Legge sulla protezione delle persone con disturbi mentali. Con tale legge è stato creato un chiaro quadro normativo per le procedure che coinvolgono persone con disturbi mentali; ancora, diverse disposizioni di tale legge si possono considerare alla stregua di chiare risposte a numerosi dilemmi etici. L'analisi di tali disposizioni, che costituisce l'oggetto di questo scritto, può servire quale indicatore rilevante della sensibilità bioetica della Legge sulla protezione delle persone con disturbi mentali.

Parole chiave: Legge sulla protezione delle persone con disturbi mentali, consenso informato, bioetica, ricerche biomediche. 